\title{
CT EVALUATION OF CHRONIC ALCOHOLIC PANCREATITIS VERSUS TROPICAL PANCREATITIS
}

Vinoo Jacob모 A.S. Krishna Kumar²

\section{HOW TO CITE THIS ARTICLE:}

Vinoo Jacob, A.S. Krishna Kumar. "CT Evaluation of Chronic Alcoholic Pancreatitis versus Tropical Pancreatitis". Journal of Evolution of Medical and Dental Sciences 2014; Vol. 3, Issue 03, January 20; Page: 698-706, DOI: $10.14260 /$ jemds/2014/1889

ABSTRACT: Chronic calcific pancreatitis is a result of chronic inflammation of the pancreas which results in irreversible damage. There are two varieties of chronic calcific pancreatitis (CCP) which is 1. Alcoholic calcific pancreatitis, 2. Tropical calcific pancreatitis, Alcoholic calcific pancreatitis is invariably related to the consumption of alcohol. CCP is a special form of chronic pancreatitis that tends to calcify and is associated with pancreatic lithiasis. Pancreatic lithiasis refers to true calculi in the duct system of the pancreas. Calculi can be due to calcification of the parenchyma. The term tropical calcific pancreatitis refers to the disease which occurs in children and young adults. In contrastACP is commonly seen in adults, in developing countries of the sub-tropics. In India, TCP is commonly seen in Kerala and Tamil Nadu. In the study conducted by Pipali DH et al ${ }^{1}$, chronic calcific pancreatitis in Western Maharashtra, the mean age of presentation of TCP was 32, and the peak age of presentation among males is 31 to 35 , and among females is 16 to 20 years. There was a predominance of males, with a male to female ratio of about $4: 1$. The patients usually present with symptoms of abdominal pain, steatorrhoea and diabetes. When diabetes is present the condition is called fibrocalcinous pancreatic diabetes. The cause of TCP remains obscure, however susceptibility mutations in the gene encoding serene protease inhibitor Kazal Type-1 (SPINK1) has been identified.

METHODS: We did a retrospective analysis of 25 proven cases of chronic calcific pancreatitis, of which 21 turned out to be of alcoholic etiology, 4 cases showed radiological features of tropical calcific pancreatitis. The study was conducted in the Department of Radio diagnosis Sree Gokulam College, Trivandrum, for a period of two years, from January 2012, to December 2013. The patients were referred mainly from the departments of Gastroenterology, and gastro surgery, with clinical features and history corresponding to CCP. RESULTS: The retrospective analysis over a two year period of patients diagnosed as chronic calcific pancreatitis showed that 18 cases were of alcoholic etiology and 6 cases had features of tropical calcific pancreatitis ACP was exclusively seen in male patients, and the TCP group had 2 male and 4 female patients, of which 3 cases had mass lesions which on biopsy were proven to be adenocarcinoma. CONCLUSION: The predominant feature of alcoholic calcific pancreatitis is that small and speckled calculi with mild dilatation of the ducts are seen. Also it is almost exclusive in males in the fourth and fifth decades. The main feature of TCP is that there will be marked fatty replacement of the gland with significant duct dilation and large, dense calculi. Our conclusions also were corroborated with the study by Chari Set $\mathrm{al}^{2}$.

KEYWORDS: Chronic Calcific Pancreatitis, Tropical Calcific Pancreatitis, Alcoholic Calcific Pancreatitis, Pancreatic Calculi.

INTRODUCTION: Chronic pancreatitis is defined as a progressive disease of the pancreas and irreversible morphological changes resulting in the gradual fibrotic replacement of the normal 
pancreatic tissue. There will be loss of exocrine and endocrine function from fibrosis and parenchymal damage. The patients usually present with abdominal pain and mal digestion. The incidence of chronic pancreatitis ranges from 1.6 to 23 cases per 1 lakh per year, worldwide. There has been a gradual increase in the incidence in some countries, which can be attributed to increase in alcohol consumption, and early diagnosis.

Grossly, the pancreas may be enlarged or atrophic in size with or without calcification. The ducts maybe dilated, irregular or strictured. The proponents of "stone and duct" obstructive theory have postulated that alcohol increases the lithogenecity of pancreatic juice leading to stone formation. Heavy and prolonged alcohol use is the most common cause of chronic pancreatitis. Chronic pancreatitis is commonly associated with severe pain, extensive calcification, and ductal changes. Most patients experience recurrent episodes of acute pancreatitis for severe years before chronic pancreatitis develops. Smoking and high fat diet may also contribute to the pancreatic disease in alcoholics. This is also corroborated by the study by Robert Jet $\mathrm{al}^{3}$.

Tropical pancreatitis is endemic to certain developing countries such as India, Africa and South America. Episodic abdomen pain begins in childhood, and is followed by rapid progression to endocrine and exocrine insufficiency. Nutritional factors such as dietary toxins and micro nutrient deficiency such as zinc, copper and selenium maybe involved in the pathogenesis of tropical pancreatitis.

Causes of obstructive calcific pancreatitis include conditions like pancreatic adenocarcinoma and neuroendocrine tumors. It is frequently associated with auto-immune diseases such - Sjogren syndrome and primary sclerosing cholangitis.

Hereditary pancreatitis is a rare autosomal dominant disease that causes recurrent painful episodes of acute pancreatitis in childhood, leading to chronic pancreatitis and pancreatic carcinoma in children. The cardinal features of chronic pancreatitis are - pancreatic atrophy, calcification, and pancreatic duct dilatation. Similar findings were seen in the study by A.I. De Backeret $\mathrm{al}^{4}$

MATERIALS AND METHODS: We did a retrospective analysis of 25 proven cases of chronic calcific pancreatitis of which 21 were alcoholic calcific pancreatitis and 4 cases were proven to be tropical calcific pancreatitis. One case of TCP had a mass lesion in the body of pancreas, which on biopsy was proved as adenocarcinoma.

The equipment used for the study was GE Hi-speed Dual CT scan machine. Serial $5 \mathrm{~mm}$ sections were taken from the domes of the diaphragm till the pelvis which was followed by IV contrast study in arterial, portal venous and delayed phases. The contrast used for the study was 70 to $100 \mathrm{cc}$, depending upon the body weight of the patient. Oral contrast was also given for delineating the bowel loops adjacent to the head of pancreas. Factors $130 \mathrm{KV}$ and $70 \mathrm{MA}$ were a constant for all cases.

DISCUSSION: Chronic Calcific Pancreatitis is the end result of continuous prolonged inflammatory, and fibrosing process that affects the pancreas, which results in irreversible morphological changes and produces permanent endocrine and exocrine pancreatic dysfunction. Thus CCP is the progressive irreversible destruction of the pancreas due to chronic inflammation. This can be of two possibilities

- Chronic Relapsing Pancreatitis

- Chronic pancreatitis (persistent) 
This can be again divided into two types

○ Chronic non-calcifying pancreatitis

- Calcifying pancreatitis

This can be either in the duct or the parenchyma of the pancreas

CCP is more commonly seen in the southern part of Kerala where consumption of tapioca is more. ACP is related to the consumption of alcohol and smoking. Inflammatory disease of pancreas can either be acute or chronic. Acute pancreatitis is less common in children than in adults. The pancreas has got endocrine and exocrine functions. The endocrine function produces three hormones, two these hormones, insulin and glucagon are essential for the processing of sugars in the diet. The third hormone produced by the endocrine cells of the pancreas effects the gastrointestinal functioning. This hormone is also known as vasoactive intestinal polypeptide. The exocrine function produces a variety of digestive enzymes such as trypsin, chymotrypsin, Lipase and amylase. CCP is the special form of chronic pancreatitis that tends to calcify and is associated with pancreatic lithiasis, which refers to calculi in the duct system of the pancreas or due to the calcification of the pancreatic parenchyma. ACP is the common most type of chronic pancreatitis seen in the western world. In the tropics, a distinct non-alcoholic chronic pancreatitis of uncertain etiology known as TCP is commonly seen. The commonest causes for CCP are:

1. Alcohol consumption:

In our study, this was found to be $80 \%$ main cause

2. Stones in biliary tree - rare cause

3. Malnutrition, diet

4. Hyperparathyroidism

5. Hereditary (familial hereditary pancreatitis)

6. Idiopathic - $20 \%$ - as mutation

7. Trauma

8. Congenital anomaly (pancreatic divisum)

9. Cystic fibrosis

10. Autoimmune pancreatitis

11. Hyperlipidaemia

These findings were recorded in the studies: Mahurkar S5and Barman $\mathrm{KK}^{6}$ and Mohan V7.

A variety of factors are implicated in CCP, such as focal necrosis, segmental or diffusion fibrosis, parenchymal calcification or ductal stones, or stricture or dilation of the duct. This was also recorded in the study by Minagi $\mathrm{H}$ and Mangolin $\mathrm{F}^{8}$. CCP is invariably related to alcohol consumption, the earliest finding of which is precipitation of proteinaceous material. In the pancreatic duct, that forms protein plugs, which subsequently calcify. Initially the duct and lobules are involved in a random manner. The pancreatic duct epithelium undergoes atrophy, hyperplasia and metaplasia at the site of the protein plugs. As a result, many of the pancreatic ducteoles dilate while others are obliterated by fibrosis. In approximately $50 \%$ of the patients with CCP, the pancreatic parenchyma contains cysts of varying sizes.

The main clinical features that the patient present with are:

1. Debilitating abdominal pain in epigastric region (80\%) that may be episodic or continuous in nature. This pain may be is due to a number of reasons like - irritation of retropancreatic 


\section{ORIGINAL ARTICLE}

nerves, ductal dilation and stasis, or due to chronic inflammation itself. The pathogenesis of pain in CCP is multifactorial caused due to factors such as circulating oxygen, free radicles and pancreatic obstruction.

2. Exocrine dysfunction: The Diarrhoea, asthenia, loss of weight and appetite, steatorrhoea

3. Endocrine dysfunction: Diabetes mellitus. Pancreatitic diabetes may often be typically brittle because of concomitant glucagon deficiency and requires insulin

4. Mild jaundice is due to narrowing of retropancreatic bile duct and cholangitis

The complications of CCP can be summarized as follows:

- Pseudocyst of pancreas

- Pancreatic ascites

- CBD stricture due to oedema or inflammation

- Portal thrombosis - segmental portal hypertension

- Carcinoma pancreas

- Pancreatic pleural effusion, pancreatic ascites

- Splenic vein thrombosis

The main investigations that are carried out are:

- Serum amylase

- Blood sugar

- Liver function tests and prothrombin time

- U/S abdomen to seen duct dilation, stones, parenchyma, liver status, CBD (normally, diameter of pancreatic duct $<3 \mathrm{~mm}$ )

- Endosonography

- CT scan - CT guided FNAC

- ERCP - chain of lake appearance. Duct is dilated

- MRCP

- Plain x-ray shows calcification in $65 \%$ of patients

- Pancreatic secretory function analysis

The main imaging findings of Tropical calcific pancreatitis are dilatation of the pancreatic duct and its side branches, irregularity of the duct caliber, atrophy of the pancreas, and parenchymal calcification. In addition there can be other findings such as - smooth and tapered strictures of the MPD or terminal branches, pancreatic fluid collections, focal or diffuse enlargement of the pancreas, alterations in peripancreatic fat or perirenal fascia, splenic vein occlusion, peripancreatic pseudoaneurysm. Our findings were found to be consistent with the study by KK Barma ${ }^{9}$ and Rossella Graziani et al $^{9}$. 
ORIGINAL ARTICLE

\begin{tabular}{|l|l|l|}
\hline \multicolumn{1}{|c|}{ FEATURES } & \multicolumn{1}{c|}{$\begin{array}{c}\text { TROPICAL CHRONIC } \\
\text { PANCREATITIS }\end{array}$} & \multicolumn{1}{c|}{$\begin{array}{c}\text { ALCOHOLIC CHRONIC } \\
\text { PANCREATITIS }\end{array}$} \\
\hline Sex ratio M:F & $70: 30$ & Almost all male \\
\hline Age at onset & Second and third decades & Fourth and fifth decades \\
\hline Socioeconomic status & Usually poor, may occur in others as well & $\begin{array}{l}\text { All strata of society } \\
\text { equally affected }\end{array}$ \\
\hline Course of diabetes & More aggressive and accelerated & Slower rate of progression \\
\hline Diabetes & Occurs in > 90\% & About 50\% of cases \\
\hline Alcoholism & Absent by definition & Heavy alcohol abuse \\
\hline $\begin{array}{l}\text { Prevalence of } \\
\text { pancreatic cancer }\end{array}$ & Very high & $\begin{array}{l}\text { Higher than in the } \\
\text { general population }\end{array}$ \\
\hline $\begin{array}{l}\text { Appearance of } \\
\text { pancreatic calculi }\end{array}$ & $\begin{array}{l}\text { Large and dense } \\
\text { with discrete margins }\end{array}$ & $\begin{array}{l}\text { Usually small and speckled } \\
\text { with ill-defined margins }\end{array}$ \\
\hline Location of calculi & Always in large ducts & Usually in small ducts \\
\hline Ductal dilation & Usually marked & Usually mild \\
\hline Fibrosis of gland & Marked & Less severe \\
\hline Fatty replacement of gland & More common & Less common \\
\hline \multicolumn{1}{|l|}{ The synopsis of syndromes in biliary and non-biliary } \\
\hline
\end{tabular}

Synopsis of Nonalcoholic, Nonbiliary Pancreatitis Syndromes

\begin{tabular}{|c|c|c|c|c|c|}
\hline Entity & Demographic Features & Etiopathogenesis & Laboratory Findings & Clinical Features & Imaging Features \\
\hline Autoimmune pancreatitis & $\begin{array}{l}\text { Age, } 60-70 y \text {, male } \\
\text { preponderance }\end{array}$ & $\begin{array}{l}\text { Autoantibodies against } \\
\text { duct epithelium }\end{array}$ & $\begin{array}{l}\text { Antinuclear, antilactoferrin, } \\
\text { anti-smooth muscle, and } \\
\text { anti-carbonic anhydrase II } \\
\text { antibodies }\end{array}$ & \begin{tabular}{|l|} 
Acute-onset obstructive \\
jaundice, abdominal \\
discomfort
\end{tabular} & $\begin{array}{l}\text { Diffusely enlarged } \\
\text { pancreas with delayed } \\
\text { enhancement and rim; } \\
\text { diffuse narrowing of } \\
\text { pancreatic duct with } \\
\text { biliary strictures }\end{array}$ \\
\hline Groove pancreatitis & $\begin{array}{l}\text { Age, } 40-50 \text { y, male } \\
\text { preponderance }\end{array}$ & $\begin{array}{l}\text { Pancreatic heterotopia, } \\
\text { anatomic biliary } \\
\text { variations }\end{array}$ & No specific findings & $\begin{array}{l}\text { Midepigastric pain, } \\
\text { vomiting, weight loss }\end{array}$ & $\begin{array}{l}\text { Cysts in duodenal wall } \\
\text { with thickening; delayed } \\
\text { enhancing masslike } \\
\text { duodenopancreatic } \\
\text { oroove }\end{array}$ \\
\hline Tropical pancreatitis & Young adults & $\begin{array}{l}\text { Malnutrition, genetic } \\
\text { predisposition, } \\
\text { environmental factors }\end{array}$ & No specific findings & $\begin{array}{l}\text { Recurrent epigastric } \\
\text { pain, insulin-dependent } \\
\text { but ketosis-resistant } \\
\text { diabetes }\end{array}$ & $\begin{array}{l}\text { Dilated pancreatic duct } \\
\text { with intraductal calculi } \\
\text { and pancreatic atrophy }\end{array}$ \\
\hline Tuberculous pancreatitis & $\begin{array}{l}\text { Endemic regions, } \\
\text { immunocompromised } \\
\text { patients }\end{array}$ & $\begin{array}{l}\text { Hematogenous or } \\
\text { lymphatic spread from } \\
\text { primary location }\end{array}$ & $\begin{array}{l}\text { Tuberculous antibodies, } \\
\text { positive Mantoux test } \\
\text { result }\end{array}$ & $\begin{array}{l}\text { Abdominal pain, } \\
\text { anorexia, weight loss }\end{array}$ & $\begin{array}{l}\text { Low-attenuation } \\
\text { pancreatic mass, } \\
\text { low-attenuation } \\
\text { retroperitoneal lymph } \\
\text { nodes }\end{array}$ \\
\hline Hereditary pancreatitis & $\begin{array}{l}\text { Children and young } \\
\text { adults }\end{array}$ & Genetic mutations & No specific findings & $\begin{array}{l}\text { Mild disease with slow } \\
\text { progression }\end{array}$ & $\begin{array}{l}\text { Pancreatic duct } \\
\text { dilatation with } \\
\text { parenchymal atrophy }\end{array}$ \\
\hline $\begin{array}{l}\text { Pancreatitis associated } \\
\text { with hypercalcemia }\end{array}$ & Hyperparathyroidism & $\begin{array}{l}\text { Calcium deposition in } \\
\text { pancreatic duct or } \\
\text { trypsinogen activation } \\
\text { induced by calcium }\end{array}$ & $\begin{array}{l}\text { Hypercalcemia, high } \\
\text { parathyroid levels }\end{array}$ & $\begin{array}{l}\text { Severe acute epigastric } \\
\text { pain }\end{array}$ & $\begin{array}{l}\text { Neck ultrasound, } \\
\text { neTc-sestamibi } \\
\text { scintigraphy may show } \\
\text { parathyroid adenoma }\end{array}$ \\
\hline $\begin{array}{l}\text { Pancreatitis associated } \\
\text { with hypertriglyceridemia }\end{array}$ & $\begin{array}{l}\text { Pregnant women, } \\
\text { obese persons with } \\
\text { poorly controlled } \\
\text { diabetes }\end{array}$ & $\begin{array}{l}\text { Accumulation of free } \\
\text { fatty acids producing } \\
\text { acinar cell and } \\
\text { pancreatic capillary } \\
\text { injury }\end{array}$ & $\begin{array}{l}\text { Serum triglyceride level } \\
>1,000 \mathrm{mg} / \mathrm{dl}\end{array}$ & $\begin{array}{l}\text { Severe acute epigastric } \\
\text { pain }\end{array}$ & $\begin{array}{l}\text { Enlarged pancreas with } \\
\text { surrounding inflamma- } \\
\text { tory changes }\end{array}$ \\
\hline
\end{tabular}

This is also seen in the study done by Ring EJ11

Journal of Evolution of Medical and Dental Sciences/ Volume 3/ Issue 03/January 20, 2014 


\section{ORIGINAL ARTICLE}

We did a retrospective analysis of 24 cases over a period of two years from January 2012, to December, 2013. Majority of the cases had features of Alcoholic Pancreatitis. 6 cases showed features of Tropical calcific pancreatic with ductile calculi, fatty replacement of the gland and fibrosis, of this 3 cases had mass lesions, of which two which were biopsy proven adenocarcinoma. The other finding that was observed was that ACPs was exclusively seen in males in the fourth and fifth decades. On the other hand TCP was predominately seen in females, with a male to female ratio of 1:2. Most of patients of TCP had diabetes at the time of scanning. The incidence of TCP has been linked to the consumption of tapioca, in Kerala. This was noted in the study by Thomas PG'12.

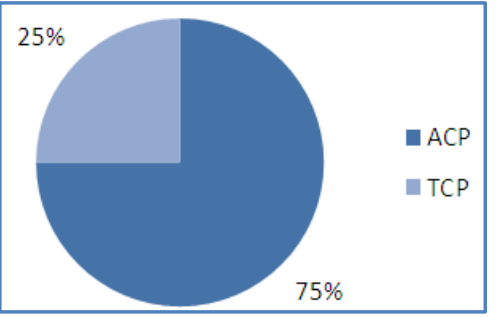

Fig. 1: The Distribution of ACP, and TCP cases in our study

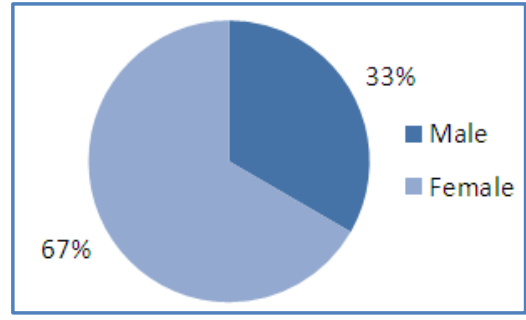

Fig. 2: The distribution of male and female cases in our study of Tropical calcific pancreatitis cases

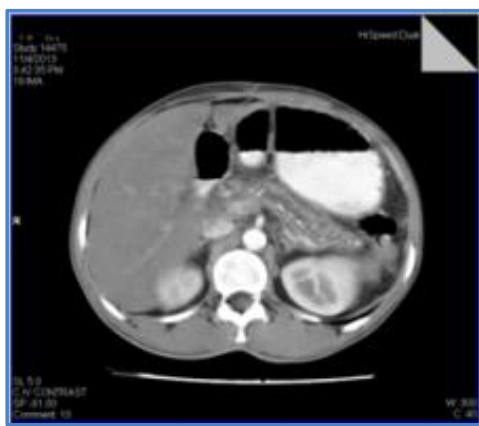

Fig. 3

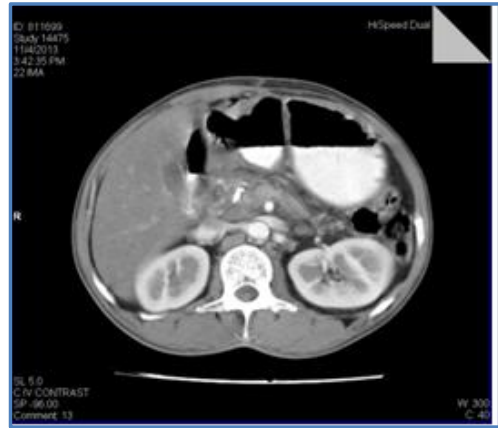

Fig. 5

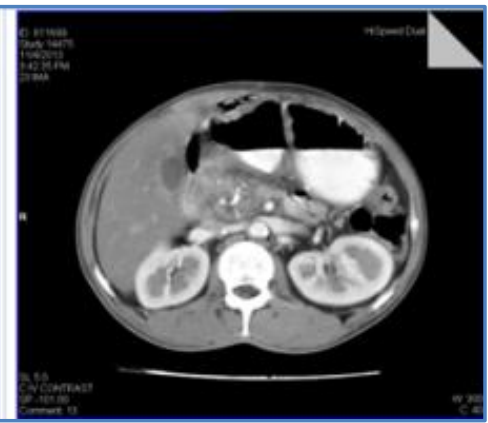

Fig. 4

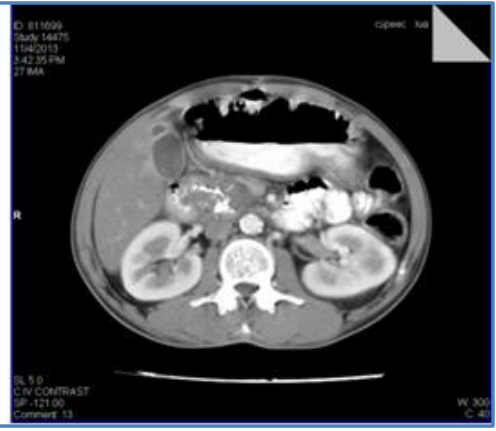

Fig. 6

Axial CT sections through the pancreas of a 42 year old male patient diagnosed as ACP showing ductal dilation withmulitple small speckled calculi within it. 


\section{ORIGINAL ARTICLE}

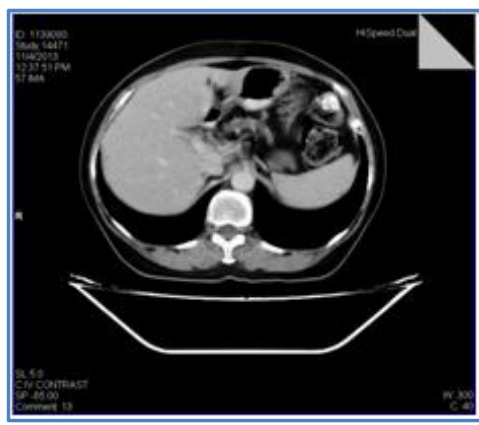

Fig. 7

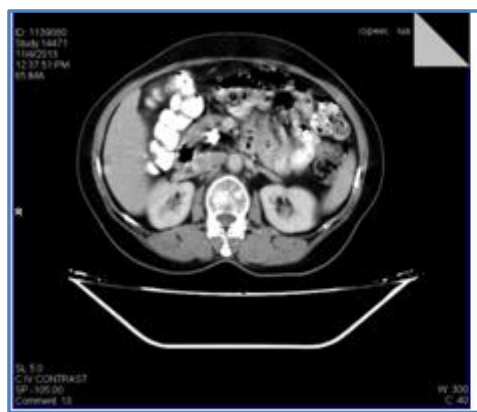

Fig. 9

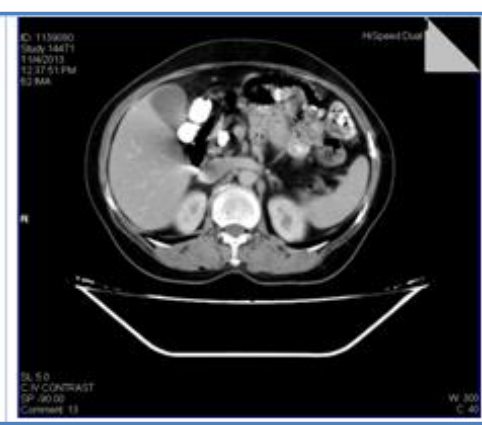

Fig. 8

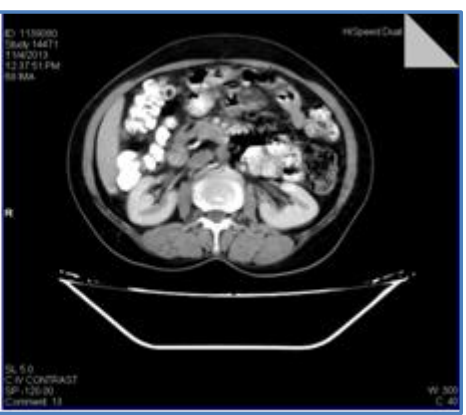

Fig. 10

Axial CT sections through the pancreas of 64 year old female patient showing diffuse fatty replacement of pancreatic parenchyma with significantly dilated duct and a large calculus at the region of head of pancreas.

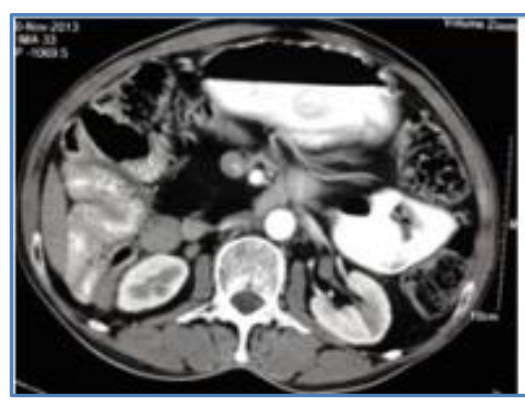

Fig. 11

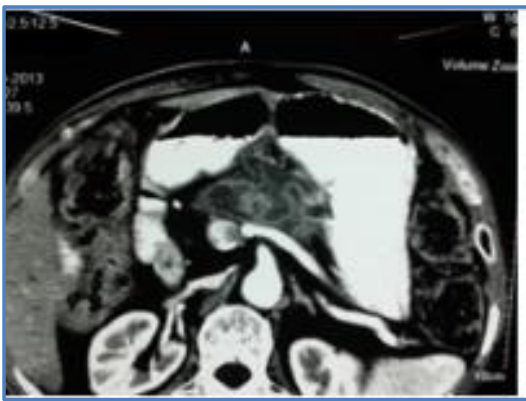

Fig. 13

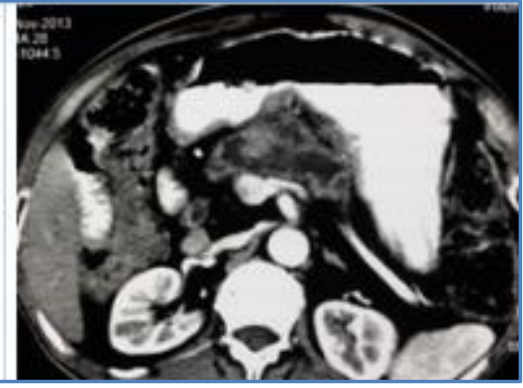

Fig. 12

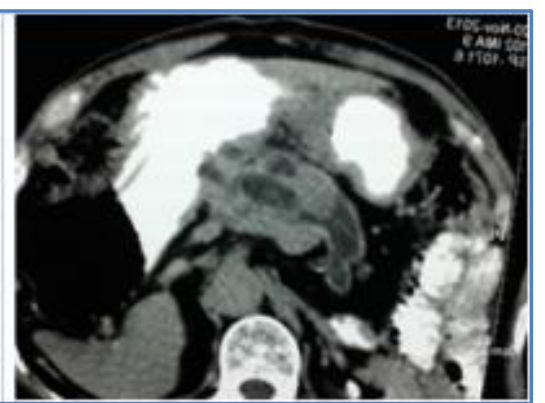

Fig. 14 
Axial CT sections through the pancreas of 57 year old female patient showing fatty replacement of pancreatic parenchyma with a mass leasion(adenocarcinoma) involving the body and tail of pancreas with dilated duct.

\section{Abbreviations:}

- ACP: Alcoholic Calcific Pancreatitis

- CCP: Chronic Calcific Pancreatitis

- TCP: Tropical Calcific Pancreatitis

\section{REFERENCES:}

1. Pipali DH, Naik SR, Ratnan VJ: Chronic calcific pancreatitis in Western. Maharashtra, J of postgraduate medicine1987; 33(4):201-5.

2. Chari S, Jayanthi V, Mohan V, Malathi J: Radiological Appearance of pancreatic calculi in tropical versus alcoholic pancreatitis. J Gastroenterology and Hepatology 1992; 7(1): 42-44.

3. Robert J. Lesniak, Mark D. Hohenwalter, Andrew J. Taylor: Spectrum of Causes of Pancreatic Calcifications. AJR 2002; 178:79-86.

4. A.I. De Backer, K.J. Mortelé, P.R. Ros, D. Vanbeckevoort, B. De Keulenaer: Chronic pancreatitis: diagnostic role of computed tomography and magnetic resonance imaging. JBR-BTR2002; 85: 304-310.

5. Mahurkar S, Reddy DN, Rao GV, Chandar GR: Genetic mechanisms underlying the pathogenesis of tropical calcific pancreatitis. World J Gastroenterology 2009; 15:264-269.

6. Barman KK, Premalatha G, Mohan V: Tropical Chronic Pancreatitis. Post Grad Medical J 2003; 79:606-615.

7. Mohan V, Premalatha G, Pitchumani CS: Tropical Chronic Pancreatitis, an update. J Clinical Gastroenterology 2003; 36:337-346.

8. Minagi H, Mangolin F: Pancreatic Calcification. Am J Gastroenterology 1972L; 57:139-145.

9. Rossella Graziani, Margherita Tapparelli, Roberto Malagò, Veronica Girardi, Luca Frulloni, Giorgio Cavallini, Roberto PozziMucelli: The Various Imaging Aspects of Chronic Pancreatitis: AISP - 28th National Congress2004 October: 28-30.

10. Abhijit Sunnapwar, Srinivasa R. Prasad, Christine O. Menias, et al: Nonalcoholic, Nonbiliary Pancreatitis: Cross-Sectional Imaging Spectrum. AJR 2010; 195:67-75.

11. Ring E.J, Eaton SB, Ferrucci JT, Short WF: Differential Diagnosis of pancreatic calcification AJR; 117:446-452.

12. Thomas PG, Augustine P, Ramesh H: Observation and surgical management of Tropical pancreatitis in Kerala and Southern India: World J surgery 1990; 14:32-41. 


\section{ORIGINAL ARTICLE}

\section{AUTHORS:}

1. Vinoo Jacob

2. A.S. Krishna Kumar

\section{PARTICULARS OF CONTRIBUTORS:}

1. Associate Professor, Department of Radio diagnosis, Sree Gokulam Medical College and Research Foundation.

2. Associate Professor, Department of Radio diagnosis, Sree Gokulam Medical College and Research Foundation.

\section{NAME ADDRESS EMAIL ID OF THE} CORRESPONDING AUTHOR:

Dr. Vinoo Jacob, Associate Professor, Sree Gokulam Medical College and Research Foundation, Venjaromoodu P.O., Thiruvananthapuram - 695607. Email - drvinoojacob@hotmail.com

Date of Submission: 27/12/2013.

Date of Peer Review: 28/12/2013.

Date of Acceptance: 07/01/2014.

Date of Publishing: 16/01/2014. 